\title{
ASSESSMENT OF THE AWC TRUclean PROCESS FOR USE ON MOUND SOILS AND SEDIMENTS.
}

\author{
D. R. Rogers \\ Science Fellow \\ EG\&G Mound Applied Technologies \\ March 23, 1989
}

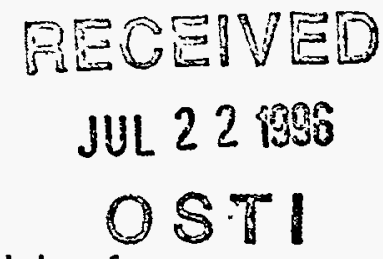

contaminated particles from coarse low-density sand on Johnston Island.

The soils and sediments at Mound have a high silt-clay content and this silt-clay size-fraction contains virtually all the contamination. A review of the 1987 soil decontamination tests at the Nevada Test Site (NTS), revealed that AWC overestimated the effectiveness of the TRUclean Process for the type of contaminated soil and sediments at Mound. After a re-evaluation of the test data collected by AWC, the volume reduction predicted for Mound WD Hillside soil ranges from 20.2 to $28.4 \%$ depending on plutonium concentration. The volume reduction for Miami-Erie Canal sediments is predicted to be near zero.

Based on the Process components and the characteristics of the local contaminated soils and sediments, it is concluded that the current TRUclean Process is inappropriate for use at Mound. Further, even if the TRUclean Process was specifically designed and optimized to separate the contaminated fraction of the Miami-Erie Canal sediment, it could not be improved sufficiently to be cost effective. The contaminated clay-fraction is just too

The current TRUclean Process was designed to separate dense 
abundant and there is no way to mechanically or physically separate "hot" and "cold" clay particles. In addition, AWC has given little attention to controlling airborne contamination; this is not an insignificant problem for this process. With the current plans and designs for TRUclean, the process would have to be operated in a containment facility if it is to be used anywhere but the most remote locations.

With the disposal cost for contaminated soils so expensive and potential rewards of developing "THE SOIL DECONTAMINATION MACHINE" so great, it is to be expected that developers will oversell the applicability and effectiveness of their product. A single-process solution to all soil decontamination applications will be difficult to find because there is not just one problem; every soil presents a different challenge.

A general process for decontamination of soil should not be expected and should be viewed with suspicion.

Separation techniques selected for a soil decontamination process should be tailored to the characteristics of the radionuclide, the characteristics of the soil, and the way the contamination is distributed in the soil. The decontamination strategy should be decided only after the contaminated soil has been carefully characterized and studied. The trial and error method of process selection will be ineffective, expensive, and dangerous.

\section{THE REVIEW}

The review included an evaluation of the "Gravity" technology based on published material. The TRUclean Process was evaluated after examination of the AWC reports and many telephone discussions with Terry Wenstrand and Al Western of AWC. The Mound soil test data review and assessment was conducted by requesting all available raw data taken during the Mound Soil Trials at NTS in 1987. Terry Wenstrand, AWC, concurred with the conclusions reached during the review and evaluation of the data, including the performance of single runs and the amount of "clean" discharge that might be produced using duplex processing.

The amount of waste generated by the TRUclean Process was apparently not a matter of record at AWC. This was estimated after a discussion with AWC on potential sources of waste generation, including the filter precoat and waste water. There may be considerable error in the estimates for the current process and future projections. The mutually agreed waste generation rates, however, are thought to be conservatively low. Estimates of the staffing required to operate equipment capable of processing 8 cubic yards of soil per hour were reviewed with AWC.

Independent views on the "gravity" technology and the TRUclean Process were gathered from technical and management observers who have seen the TRUclean Process in operation including J.J. Blakeslee, R. L. Kochen, 


\section{DISCLAIMER}

This report was prepared as an account of work sponsored by an agency of the United States Government. Neither the United States Government nor any agency thereof, nor any of their employees, makes any warranty, express or implied, or assumes any legal liability or responsibility for the accuracy, completeness, or usefulness of any information, apparatus, product, or process disclosed, or represents that its use would not infringe privately owned rights. Reference herein to any specific commercial product, process, or service by trade name, trademark, manufacturer, or otherwise does not necessarily constitute or imply its endorsement, recommendation, or favoring by the United States Government or any agency thereof. The views and opinions of authors expressed herein do not necessarily state or reflect those of the United States Government or any agency thereof. 
and Keith Gilbert of Rocky Flats and R. R. Jaeger, J. R. Geichman, and D. G. Draper of Mound. A video tape, produced by AWC showing the TRUclean Process in operation at Johnston Island, was viewed. The opinions of $R$. A. Neff, C. S. Friedman, and D. G. Carfagno at Mound were sought on environmental considerations and the outlook for developing an acceptable Pu soil concentration standard that would be regarded by USEPA and others as "below regulatory concern".

A limited literature survey and previous discussions with knowledgeable colleagues at other DOE sites were useful to define a sampling of the available information concerning:

(1) the types of contamination events,

(2) characteristic physical chemical form of the plutonium,

(3) the size distribution of the soils, and

(4) size and density distribution of the plutonium within soil/sediment matrix.

Some information was gathered on the particle size and density distribution data of soils/sediment at Nevada Test Site (NTS) Area 13, NTS Area 11, Rocky Flats (RF), Mound, Johnston Island, and other locations.

\section{CONCLUSIONS}

Following the review and evaluation of available information, a number of conclusions were reached about the AWC TRUclean Process, its potential for use on a variety of contaminated soils, and its application to Mound soils and the Miami-Erie Canal sediments. These conclusions are listed below then discussed in detail in the Analysis and Discussion section.

1. The TRUclean Process is technologically sound, but does not represent a breakthrough in soil decontamination.

2. The TRUclean Process, as it stands, is not a generalized method for decontaminating a wide range of contaminated soils. It is currently applicable only to some types of soil when the contamination is distributed in the soil as a function of density.

3. The TRUclean Process components are not appropriate for decontaminating Mound soils or the Miami-Erie Canal sediments.

4. AWC overestimated the potential effectiveness of the TRUclean Process for Mound WD Hillside soil.

5. The net volume-reduction offered by TRUclean for the sediment in the Miami-Erie Canal is predicted to be near zero. 


\section{ANALYSIS AND DISCUSSION}

1. The TRUclean Process is technologicallY sound. but does not represent a breakthrough in soil decontamination.

The TRUclean Process, as it currently exists, is shown schematically in Figure 1. The contaminated soil must be dried and partially hand sorted to remove organic material and trash prior to the screening and crushing step in the process (Wenstrand, AWC; Blakeslee, RFP; Jaeger, Mound). The soil is transported to the process and placed in a large hopper. Dry-screening is used to collect the material requiring size reduction. The material which passes the screen falls onto a conveyer. The oversized material goes to a crusher then onto the conveyer system. The conveyer levels the material to a uniform thickness and transports the soil under a radiological sorter. This devise is a gamma counter that measures the 60-kev gamma-ray from americium-241 to assay/monitor the feed material and to divert lightly contaminated portions of the feed soil from the conveyer.

The feed material is next processed by the "Selective Mineral Separator" (SMS) which separates the material according to density. The contaminated concentrate is collected in the SMS while the remainder of the material passes onto the spiral classifier which de-waters the "clean soil" discharge. An auger in the spiral classifier continuously feeds the de-watered discharge onto a conveyer that levels the material to a uniform thickness.
The conveyer moves the discharge material under another radiological sorter which is used to measure the contamination in the discharge and to detect hot spots. These hot spots can then be removed manually or by an automatic diversion gate (Wenstrand, AWC). If the discharge is still too contaminated to discard without restriction, the discharge is stored and reprocessed through the machine until a clean discharge is produced or until there is no further improvement.

The water removed from the discharge by the spiral classifier then passes through sedimentation tanks where the fine residue are allowed to settle. Finally, the water is pumped to a plate and frame filter press (Wenstrand, AWC) to remove the remainder of the suspended clay from the water. The filtered water is then recycled back to the Selective Mineral Separator.

At the heart of the TRUclean Process is the Selective Mineral Separator which is a mirieral jig. It is based on very old technology used to concentrate ores in the mining industry. Mineral jig processing was used extensively in the 19 th and early 20th century to concentrate minerals from ores according to their densities. It is used now mainly to separate pyrites from coal.

The mineral jig, shown schematically in Figure 2, is basically a pulsed fluidized particle bed. The diaphragm pump in the hutch of the mineral jig pulses water through a screen covered with layers of steel shot into the particle bed which is continuously fed with fresh 
feed. The stroke of the pulse into the bed is about $1 / 4$ to $1 / 2$ inch and the frequency is usually 150 to 400 cycles/min. A cycling water valve supplies water to the hutch on the backstroke of the diaphragm pump to prevent drawing water from the particle bed into the hutch.

The separation of particles is based on differential particle acceleration. A dense particle, settling in a fluid, reaches terminal velocity faster than a less dense particle of same settling characteristics. Therefore, in the time period before both particles reach terminal velocity, the dense particle will settle faster even though the two particles will later settle with the same terminal velocity.

The action in the mineral jig, alternatively dilating then allowing the fluidize particle bed to contract lor settle), repeatedly initialize the sedimentation cycle and multiplies the density effect in the sedimentation process. As the bed dilates with the pulse of water, the light particles are carried upward relative to the dense particles. When the bed is allowed to contract, the dense particles move downward relative to the light particles. Finally as this process continues, the bed becomes stratified according to density with the most dense particles at the bottom and the least dense particles at the top. The lightest particles and the particles less than about $50 \mu \mathrm{M}$ overflow the bed to the discharge and are carried to the spiral classifier. Within each of the density layers, the particles in the bed further stratify according to size. Ultimately the small dense particles are drawn through the steel shot-packing and the screen into the collection hutch.

The effectiveness of such a density separation depends on both particle sizes and differences in density between the dense and the less dense particles. Estimates of these effects are presented in Table 1. When the particles are in a size range known as the Newtonian sedimentation region (particles greater than about 2 millimeters), the time required for particles to reach terminal velocity range from a fraction of several seconds. Particles with relatively small density differences can be separated effectively in this size region.

As the size of the particles become smaller, into the transition "Allen Region" ( $2 \mathrm{~mm}$ down to about 100 $\mu \mathrm{M})$, the time required for the particles to reach terminal velocity decreases; therefore, the advantage offered by the differential acceleration declines. In this region, larger differences in densities are required for separations to be effective. The jigging process becomes ineffective at particle sizes near the Stokes sedimentation region where terminal velocity is reached almost instantaneously (microseconds to milliseconds). A density separation using the mineral jig becomes unlikely in the Stokes region, regardless of the density difference.

The size range for onset of the nearzero differential acceleration time depends on the density of the particles, for example, about $6 \mu \mathrm{M}$ for quartz particles, $2.65 \mathrm{~g} / \mathrm{cc}$; about $35 \mu \mathrm{M}$ for a plutonium dioxide particles, $11.4 \mathrm{~g} / \mathrm{cc}$; 
and about $27 \mu \mathrm{M}$ for plutonium metal, $19.8 \mathrm{~g} / \mathrm{cc}$. While it might be theoretically possible to make jig density separations down to these small sizes, the physical practicalities are such that the equipment does not work on particles much less than about $50 \mu \mathrm{M}$. These tiny particles simply overflow the top of the fluidized particle bed regardless of their density.

The technology used in TRUclean in not new. Except for the gamma scanning radiological sorting systems, and other radiometric measuring systems which are innovative, the key pieces of equipment are in common industrial use today.

2. The TRUclean Process. as it stands, is not a generalized method for decontaminating a wide range of contaminated soils. It is currently applicable only to some types of soil when the contamination is distributed in the soil as a function of density.

The TRUclean Process, as it currently exists at NTS, is in fact, a collection of process equipment in an early stage of development. This pilot plant type system was apparently assembled to demonstrate the principle of processing contaminated soil to reduce LSA waste and backfill volumes.

The objective of the current TRUclean Process is to separate the contamination from the soil on the basis of density. The process was originally to test the feasibility of concentrating dense contaminated particles present in the coarse coral sand on Johnston Island. In 1962, a THOR missile fitted with a nuclear weapon for a high altitude test was aborted and dispersed by the chemical explosion on the launch pad at Johnston Island. Radioactive debris was scattered over the Island, most of which was picked up, graded off, covered with clean fill, stabilized with oil, or otherwise decontaminated.

The current condition is that dense contaminated "hot particles" are mixed among the coarse coral sand. Typically, a 100-gram sample of highly contaminated sand may only have a single particle in it. These "hot particles" are relatively large and many are substantially more dense than the coral sand matrix. The chemical forms discovered include metal (stainless steel, uranium), wire, oxides, contaminated debris, and contaminated coral. Density separation of the "hot particles" from this coarse sand using the TRUclean Process seems to be appropriate and apparently is successful.

However, the nature of contaminated soils and therefore the treatment necessary to isolate the contaminated fractions vary greatly depending on a number of factors. An important consideration is the relationship between the contamination event and the physical/chemical form released to the soil. For example, if a particular release-event contaminates soils with "hot particles", the questions to be asked are: 
- What are the properties (size, surface area, density, etc) of these particles?

- Can any of these properties be used to affect a separation of the contamination from the soil?

If the event results in the contamination of the soil with a radioactive solution, the question becomes:

- What physical or mineral fraction of the soil will the contamination associate itself with?

- Can the contaminated fraction of the soil be preferentially separated from the remainder of the soil?

"Hot Particle" Contamination Events: The release event in many cases determines how the contamination is at least initially distributed in the soil. High explosive dispersion of dense radioactive materials or material contaminated with radioactive materials probably produces the largest and most dense "hot particles". Examples are the Johnston Island missile abortion event that produced dense particles in the coarse sand size-range shown in Table 2 , and the NTS safety shots conducted in Area 11 and Area 13 that produced dense particles dispersed in the fine sand/coarse silt size-range, as shown in Tables 3 through 6. Ultrasonification of the NTS soils do not seem to disperse smaller "hot particles" from these soils.
This and the relatively refractory nature of the contamination suggests that the particles do not exist as smaller particles attached to larger soil particles. If the "hot particles" are in a size range greater than about $100 \mu \mathrm{M}$ and the density difference between the contaminated particles and the soil particles is of sufficient magnitude to facilitate a practical separation, then the TRUclean Process density separation would be appropriate. Unfortunately, not many contaminated soils fall into this category.

An air burst nuclear test produces hot particles in the cloud with a median diameter of about $0.1 \mu \mathrm{M}$ with densities in the 3-4 $\mathrm{g} / \mathrm{cc}$ range. Very few of these particles contribute to close-in fallout at the test site. Surface or subsurface nuclear detonations produce larger hot particles in the 100 to 1000 $\mu \mathrm{M}$ range but with lower densities in the $<3 \mathrm{~g} / \mathrm{cc}$ range. Because these "hot particle" densities are very close to soil densities (2.2-2.7 $\mathrm{g} / \mathrm{cc})$ it seems unlikely that the Selective Mineral Separator Process would be appropriate for these types of contaminated soil. A separation based on particle sizes might be more effective providing the distribution of the contamination is favorable in the specific soil.

There is another important type of contaminated soil at Rocky Flats where (at least originally) the material spilled was Pu metal particles which have undergone chemical and physical changes. The contaminated soil at Rocky Flats resulted from leakage of contaminated lathe cooling-oil/carbon tetrachloride contaminated with tiny 
particles of weapon grade Pu metal and oxide. Some of the contamination may have been soluble at the time of the leak or were particles that became solubilized after being exposed to the environment.

The distribution of the plutonium in the soil matrix appears to have characteristics resembling both a particulate and a solution spill. Therefore, a significantly larger portion of the contamination in the Rocky Flats soils is in the silt and clay fractions, as shown in Table 7, than was exhibited by the Johnston Island or NTS soils. Some believe that tiny "hot particles" are tightly aggregated with larger size fractions of the soil particles. The free "hot particles" are thought to be about $1 \mu \mathrm{M}$ size or less. They are not easily dispersed even with ultrasonics and very harsh chemical treatment. One may even wonder if the harsh treatment "created" these particles.

In addition, some of the Pu which was released in solution or dissolved after the spill, have probably sorbed onto the clay fraction of the soil. Although no density distribution measurements have been made on this soil, it appears unlikely that a jig density separation would be appropriate because of the tiny size of the "hot particles". A size classification and/or surface area separation would probably be more effective, especially if the combination of ultrasonic and harsh chemical dispersion techniques are followed by hydrocyclone size fractionation and flotation separations.

Another class of particulate spill events are the airborne plutonium particulates routinely released from the stacks of plutonium chemical processing plants and deposited in the soil downwind. The distribution of the tiny amounts of Pu-238 found in the close-in downwind soils at Mound and Savannah River are virtually indistinguishable from the distributions resulting from known solution spills. Apparently, these airborne particles have dissolved in these moist eastern environs and sorbed onto the soil as a function of surface area or ion exchange capacity. The greater solubility of these particulates may perhaps be related to their smaller size (having passed through HEPA filters), less refractory chemical forms, and/or their greater specific activity (Pu-238 vs Pu-239).

Solution Release Events: The nature of contaminated soils after a release of radioactive solutions depends on the nuclide spilled, on the characteristics of the soil, and on the interactions between the nuclide and the soil. In the case of unhydrolized plutonium solutions, the plutonium sorbs almost immediately to the clay and silt fraction of the soil. The distribution coefficient, $\mathrm{Kd}$, of this sorption reaction onto clay is between $1 \times 10^{5}$ to $1 \times 10^{6} \mathrm{ml} / \mathrm{g}$, indicating that the plutonium is tightly bound to the soil colloids. The plutonium distributes itself in the soil matrix as a function of ion exchange capacity or surface area. In either case, the silt-clay fraction of the soil immobilizes virtually all of the Pu and it is not free to act alone.

Under some circumstances solution spills might result in a preferential 
deposition of contamination on a particular mineral phase. In some cases the density of the nuclide-specific mineral is sufficiently different from the soil matrix to permit a separation with the jig. This, however, rarely is the situation because most of the time the contamination deposits on clay. If the clay abundance in the soil is relatively small but still dominates the total soil surface area, then a size separation would be appropriate. If the nuclidespecific mineral is magnetite then a magnetic separation would be appropriate.

Soil Decontamination Processes: A single-process solution to soil decontamination will be difficult to find because there is not just one problem; every soil presents a different challenge. From the variety of contaminated soils described above, development of a single-process soil decontamination system should not be expected and should be viewed with suspicion.

The separation techniques currently used by TRUclean are but a small selection of ore and particle separation technologies which are available. In fact, there are other density separation techniques that are less dependent than the mineral jig on particle size and density ratios. The soil is dispersed in a liquid whose density is between the densities of the two soil fractions that are to be separated.

Separation processes can be developed using properties other than density such as magnetism, electrostatics, particle size, chemistry, and surface characteristics (flotation). One or more of these separation processes could be selected to provide effective volume reduction for many but not all of the contaminated soils. The process, however powerful, will only be cost effective if that portion of contaminated soil is a relatively small fraction of the total soil volume and the remainder of the soil can be released for unrestricted use.

Separation techniques selected for a soil decontamination process should be tailored to the characteristics of the radionuclide, the characteristics of the soil, and the way the contamination is distributed. The decontamination strategy should be decided only after the contaminated soil has been carefully characterized and studied. The trial and error method of process selection will be ineffective, expensive, and dangerous.

\section{The TRUclean Process components are not appropriate for Decontaminating Mound soils or the Miami-Erie Canal sediments.}

The major TRUclean Process components:

(1) Dry Screen/Crusher

(2) Conveyer/Radiological Sorter

(3) Mineral Jig

(4) Spiral Classifier

(5) Conveyer/Radiological Sorter

(6) Sedimentation tanks/Filter press were discussed and evaluated in a previous section.

The dry screening and crushing 
operation is inappropriate at Mound without extensive dust control measures to limit airborne suspension of the contaminated soil/sediment. While the dust suspension would not present a significant health risk to the population, we are committed to ALARA and do not wish to scare our neighbors. The visual impression of dust rising from a operation in the canal, would be justifiably perceived by the neighbors as an unnecessary risk. If such a process were to be used, it would have to be performed in a containment facility.

The radiological sorter is designed to monitor the 60-KeV Am-241 gamma ray. Americium-241 is produced by beta decay of Pu-241. Because Pu-241 is much more abundant in weapons grade Pu-239 than in Pu-238, the concentration of Am-241 in Pu-238 is much lower. The Am-241 concentration in the Pu-238 contaminated soil is too small to be useful. The alternative is to measure the Pu-238 17-KeV $\mathrm{x}$-ray but the smaller analytical sensitivity and shorter penetrating power of the $17-\mathrm{KeV} \mathrm{x}$-ray limits its usefulness in this process. The Pu-238 assay of the soil components separated by TRUclean must be performed by laboratory methods with lengthy turn around times. This negates the advantage achieved by radiological sorting.

The remaining process components are not appropriate due to the characteristics of the soil and the distribution of the Pu-238 in the soil matrix. These factors and their impact on the effectiveness of the TRUclean
Process for use on Mound soils and sediments are discussed below.

Mound WD Hillside soil was contaminated when an underground transfer line ruptured releasing acidic plutonium-238 nitrate into the calcareous soil surrounding the line. The acid was neutralized by the soil carbonates and the plutonium was quickly sorbed onto the silt-clay fraction of the soil. The WD Hillside soil is typically $50-60 \%$ silty clay and the plutonium is virtually all bound in this fraction of the soil as is shown in Table 8.

During excavation of the broken transfer line, a sudden rainstorm eroded unconsolidated contaminated soil down the W[ hillside and into the Mound drainage ditch where it mixed with uncontaminated erosion products and was carried off-site by fluvial processes into an abandoned section of the old Miami-Erie Canal. When the contaminated alluvium reached areas of low fluvial energy, it deposited as sediment in the canal bed. Subsequent erosion of non-contaminated on-site soil, following a similar scenario, diluted, covered, and finally buried the contaminated sediment.

The Miami-Erie Canal was constructed in the early 19th century and lined with clay. The canal segment near Mound has silted up with additional alluvial clay and silt along most of its length. The silt-clay fraction of the sediment in the canal ranges from about 50 to $95 \%$. The coarser material is deposited in the area near the confluence of the Mound drainage ditch with the canal. 
This is the first rapid decline in fluvial energy in this stream after it leaves the site. The affected area extends about 400 feet south and 100 feet north of the ditch and represent only about $10 \%$ of the contaminated canal. The remaining 4500 feet of the canal has the very fine (up to $95 \%$ silt-clay) deposits. The average silt-clay fraction in the canal sediment is expected to be about $85 \%$. The distribution of the plutonium in the matrix of the canal sediment is shown in Table 9.

Data presented in Figure 3, demonstrate that the plutonium is sorbed on the sediment and distributed according to either surface area or ion exchange capacity. Autoradiographic analysis ("Hollow Star" Method) of the sediment confirmed the absence of dense plutonium dioxide particles. The $\mathrm{Kd}$ (distribution coefficient) for the plutonium sorbed onto the canal sediment was in excess of 100,000 $\mathrm{ml} / \mathrm{g}$ attesting to the immobility of the contamination in the soil matrix. Table 10 shows the distribution of the sediment and the contamination according to density.

Because the contamination is not distributed as a function of density, the TRUclean Process relying on a mineral jig would not be appropriate to treat either the WD Hillside soil or the MiamiErie Canal sediments. While the spiral classifier does perform a rough size fractionation, the abundant contaminated clay fraction is not captured but passes into the water circulation system which is not designed for it.
The water recirculation system in current TRUclean Process includes sedimentation tanks and a filter press to remove the very stable clay suspension from the recirculation water. These systems are totally inadequate for the job of treating the massive amounts of clay from high clay-content soils. This is especially true when the clay is the most contaminated fraction (Wenstrand, AWC, commenting on the experience with high clay soils from the USEPA superfund sites). The filter press, used to remove the fines from the water in the current process, generates a large amount of contaminated waste as diatomaceous earth filter precoat. Wenstrand, AWC, estimates the precoat material might constitute as much as $25 \%$ of the material captured by the filter press. He mentioned the possibility of using a hydrocyclone to remove the clay in the future, but the technique is only useful down to about $10 \mu \mathrm{M}$.

The $<2 \mu \mathrm{M}$ fraction of the soil/sediment which contains most of the Pu-238 is very difficult to remove from the recirculation system. Larger sedimentation tanks or sedimentation ponds would require a great deal of additional water in the system. Ultimately the water would have to be flocculated or drummed and disposed of as contaminated waste. Clay particles require a large amount of flocculent to clarify the water and the conditions for this flocculation process are exacting.

Even after the clay has been separated from the water circulation system, it 
cannot be simply packaged, shipped, and buried in a wet condition. It must be dried or treated with a drying agent before it can be moved. The use of a drying agent is a good choice but would increase the volume of the LSA waste. De-watering and drying processes are much larger problems with clay soils than with coarser sandy soils.

Based on discussions with Terry Wenstrand, he agreed that the waste generation rate for TRUclean may well be in excess of $10 \%$ of total process throughput. Even with future modifications, it might be difficult to reduce the waste to less than $5 \%$.

4. AWC overestimated the potential effectiveness of the TRUclean Process for Mound WD Hillside Soil.

A review was conducted on the TRUclean decontamination tests performed by AWC with Mound soil in 1987. After a detailed re-examination of the raw data, data treatment methods, and "duplex" calculations, the amount of "clean" soil discharged was found to be about $44.2 \%$. Because $58.8 \%$ of the soil was processed twice, the waste generated by the process was estimated to be $15.8 \%$. Adding the estimated TRUclean Process waste to the contaminated soil fraction, means that about $71.6 \%$ of the feed volume would be LSA waste. The net volume reduction would therefore be about $28.4 \%$ rather than the $>90 \%$ projected by AWC. This data is summarized in Table 11.

The plutonium contamination in the soil selected for the test was only about $106 \mathrm{pCi} / \mathrm{g}$. Due to process waste generation, the net volume reduction would be reduced even further if the concentration of the plutonium had been more typical ; e.g, $1000 \mathrm{pCi} / \mathrm{g}$. Making the speculative assumption that the process could continue to extract $79.2 \%$ of the remaining activity on subsequent recycling runs, the discharges would have to be reprocessed several more times to produce "clean soil". It is predicted that the additional waste generation would reduce net volume-reduction to about $20.2 \%$ as summarized in Table 12.

\section{The net volume reduction offered by TRUclean for the sediment in the Miami-Erie Canal is predicted to be near zero.}

As was discussed previously, the plutonium-238 in the Miami-Erie Canal sediment is distributed as a function of surface area (or ion exchange capacity). Because the plutonium is not present as dense plutonium dioxide particles and is not sorbed preferentially on a dense mineral phase, it is not distributed in the soil as a function of density (Table 10). The sediment is mostly silty clay $(<50 \mu \mathrm{M})$ and this size fraction contains virtually all the plutonium contamination (Table 9). The average plutonium concentration of sediment which would be excavated from the canal is 
expected to be about $500 \mathrm{pCi} / \mathrm{g}$.

Based on the model developed above, the discharge would have to be recycled three times to produce a discharge with a contamination level of less than $10 \mathrm{pCi} / \mathrm{g}$. The amount of "clean discharge" produced depends on the fraction of silty clay which is estimated to be about $85 \%$. It is, therefore, expected that even if the TRUclean Process were able to totally extract all the silty clay fraction from the coarser material, the maximum "clean discharge" would only be about $15 \%$. Based on the discussion of TRUclean waste generation, it would generate more than $15 \%$ as additional waste. The TRUclean Process model projection using the current process is summarized in Table 13.

Table 14 presents the model projections if the process were optimized to remove all the contaminated silty clay from the sediment completely in a single pass to produce an absolutely clean discharge and if the process waste generation were reduced to about $5 \%$ of throughput. Even if these very favorable future improvements were achieved, the process would likely not be cost effective. The contaminated clay-fraction in the Miami-Erie Canal sediment is just too abundant and there is no way to mechanically or physically separate "hot" and "cold" clay particles. 
. 


\section{JRU clean II System}

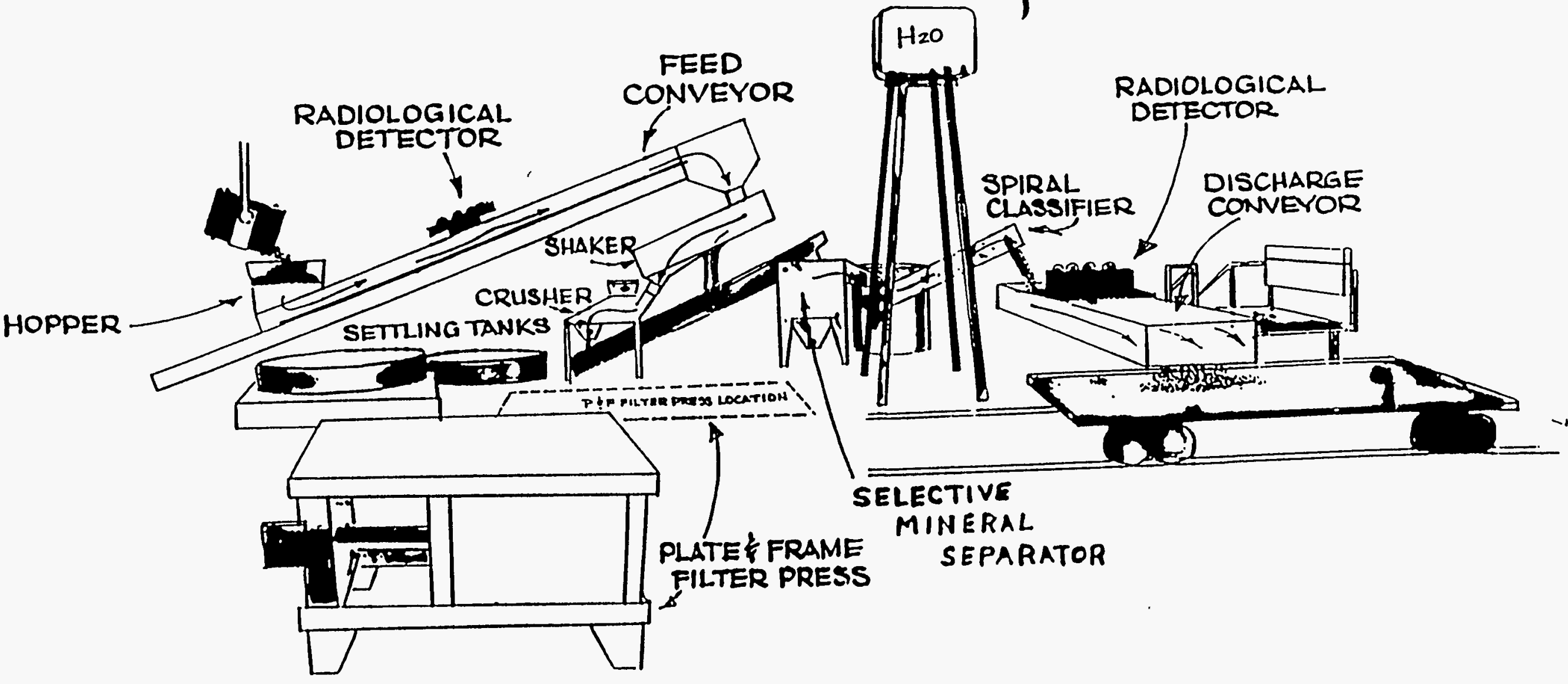

Figure 1 Basic Components of the TRUclean Sys tem 


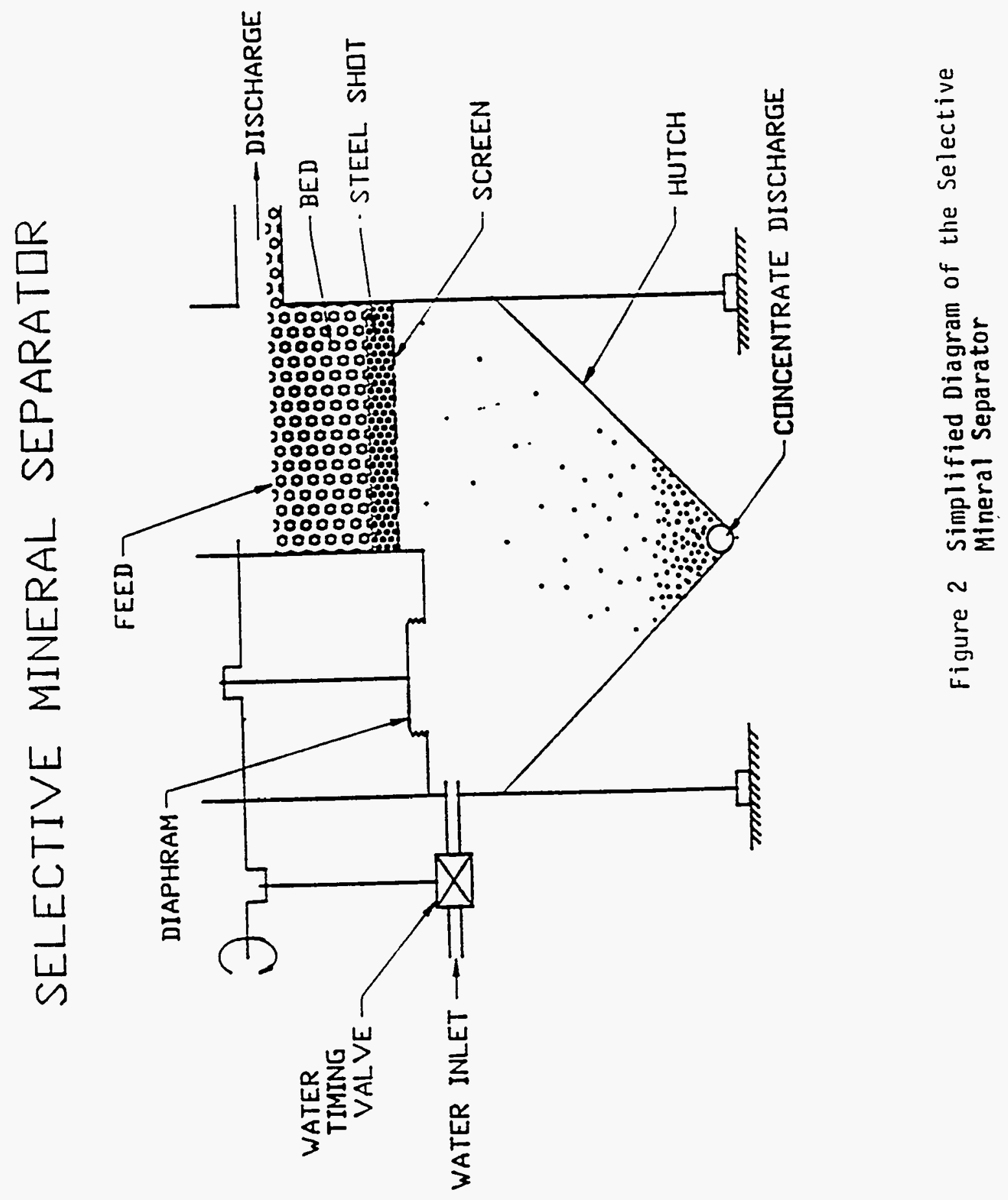




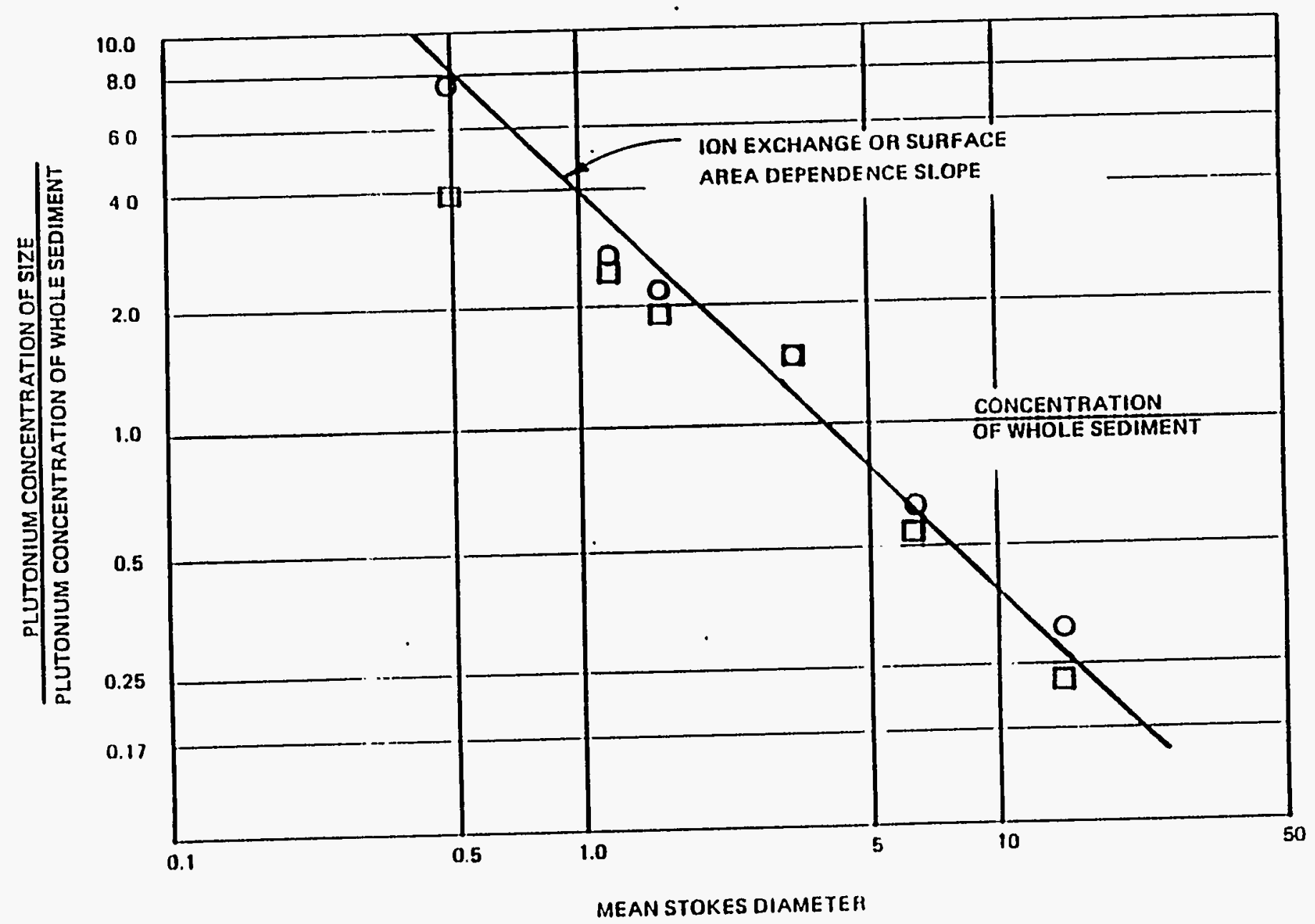

Figure 3 - Variation of ${ }^{230} \mathrm{Pu}$ concentration in sediment as a function of fully dispersed particle size. (Ropers Mound) 
Table 1

ESTIMATED DENSITY AND SIZE REQUIREMENTS FOR JIG SEPARATIONS OF A HEAVY MINERAL. PHASE FROM QUARTZ PARTICLES ${ }^{1}$

\begin{tabular}{||l|c|c|c|}
\hline $\begin{array}{c}\text { Sedimentation } \\
\text { Region }\end{array}$ & $\begin{array}{c}\text { Equation } \\
\text { Exponent } \\
\mathrm{n}\end{array}$ & $\begin{array}{c}\text { Density } \\
\text { Requirements } \\
\mathrm{g} / \mathrm{cc}\end{array}$ & $\begin{array}{c}\text { Applicable } \\
\text { Size Range } \\
\mu \mathrm{m}\end{array}$ \\
\hline \hline Stokes & - & inapplicable & $<74$ \\
\hline Allen & 0.5 & $>10$ & 74 to 150 \\
\hline Allen & 0.75 & $>4$ & 150 to 1580 \\
\hline Newton & 1 & $>3.4$ & 1680 to 6350 \\
\hline Newton & 1 & $>3$ & 6350 to 12700 \\
\hline Newton & 1 & inapplicable & $>12700$ \\
\hline
\end{tabular}

1 Density of quartz particle $=2.65 \mathrm{~g} / \mathrm{cc}$

Density of fluid (hindered) $=1.2 \mathrm{~g} / \mathrm{cc}$

Table 2

SOIL DATA FOR JOHNSTON ISLAND DISTRIBUTION OF ACTIVITY WITH PARTICLE SIZE . (Kochen, RFP)

\begin{tabular}{||c|c|c||}
\hline Size Range, $\mu \mathrm{m}$ & \% Weight & \% Activity \\
\hline$>4000$ & 42.3 & 0.5 \\
\hline 2000 to 4000 & 8.5 & 0.4 \\
\hline 1000 to 2000 & 10.4 & 39.9 \\
\hline 500 to 1000 & 10.7 & 25.5 \\
\hline 250 to 500 & 10.9 & 16.9 \\
\hline 125 to 250 & 7.9 & 9.9 \\
\hline 63 to 125 & 4.3 & 4.2 \\
\hline$<63$ & 5.0 & 2.6 \\
\hline
\end{tabular}

Types of "hot particles": Stainless steel; wire; Pu metal, oxide, coral 
Table 3

TYPICAL NTS AREA 11 SOIL DATA

PLUTONIUM DISTRIBUTION WITH PARTICLE SIZE.

(Tamura, ORNL)

\begin{tabular}{||c|c|c|}
\hline Size Range, $\mu \mathrm{n}$ & \% Weight & \% Activity \\
\hline \hline 2000 & 18.40 & - \\
\hline 840 to 2000 & 3.94 & 0.8 \\
\hline 250 to 840 & 30.13 & 10.0 \\
\hline 125 to 250 & 29.22 & 12.6 \\
\hline 53 to 125 & 13.75 & 33.6 \\
\hline 20 to 53 & 3.36 & 24.9 \\
\hline 5 to 20 & 2.37 & 15.1 \\
\hline 2 to 5 & 0.62 & 2.0 \\
\hline$<2$ & 0.67 & 1.0 \\
\hline
\end{tabular}

Table 4

TYPICAL NTS AREA 11 SOIL DATA

PLUTONIUM DISTRIBUTION WITH DENSITY

(Tamura, ORNL)

\begin{tabular}{|c|c|c|}
\hline Density Range. g/cc & \% Weight & \% Activity \\
\hline \hline$>2.9$ & 18.3 & 90 \\
\hline 2.56 to 2.62 & 43.0 & 2 \\
\hline 2.46 to 2.54 & 13.0 & 3 \\
\hline 2.26 to 2.32 & 12.1 & 2 \\
\hline 1.98 to 2.14 & 2.8 & 2 \\
\hline$<1.8$ & 0.3 & 0 \\
\hline
\end{tabular}


Table 5

TYPICAL NTS AREA 13 SOIL DATA

PLUTONIUM DISTRIBUTION WITH PARTICLE SIZE.

(Tamura, ORNL)

\begin{tabular}{|c|c|c|}
\hline Size Range, $\mu \mathrm{n}$ & \% Weight & \% Activity \\
\hline \hline 2000 & 1.61 & - \\
\hline 840 to 2000 & 3.69 & - \\
\hline 250 to 840 & 26.41 & 0.4 \\
\hline 125 to 250 & 27.37 & 2.4 \\
\hline 53 to 125 & 22.99 & 24.5 \\
\hline 20 to 53 & 7.67 & 41.3 \\
\hline 5 to 20 & 3.92 & 27.0 \\
\hline 2 to 5 & 2.17 & 2.8 \\
\hline$<2$ & 3.74 & 1.4 \\
\hline
\end{tabular}

Table 6

TYPICAL NTS AREA 13 SOIL DATA

PLUTONIUM DISTRIBUTION WITH DENSITY

(Tamura, ORNL)

\begin{tabular}{|c|c|c|}
\hline Density Range. g/cc & \% Weight & \% Activity \\
\hline \hline$>2.8$ & 5.8 & 85.2 \\
\hline 2.5 to 2.8 & 59.6 & 9.3 \\
\hline 2.3 to 2.5 & 32.2 & 5.3 \\
\hline$<1.8$ & 2.4 & 0.2 \\
\hline
\end{tabular}


Table 7

TYPICAL ROCKY FLATS SOIL DATA

PLUTONIUM DISTRIBUTION WITH PARTICLE SIZE.

(Tamura, ORNL)

\begin{tabular}{|c|c|c|}
\hline Size Range, $\mu \mathrm{n}$ & \% Weight & \% Activity \\
\hline$>2000$ & 23 & - \\
\hline 840 to 2000 & 7 & 2 \\
\hline 250 to 840 & 13 & 3 \\
\hline 125 to 250 & 13 & 2 \\
\hline 53 to 125 & 6 & 10 \\
\hline 20 to 53 & 12 & 26 \\
\hline 5 to 20 & 11 & 24 \\
\hline 2 to 5 & 6 & 28 \\
\hline$<2$ & 10 & 5 \\
\hline
\end{tabular}

Table 8

TYPICAL MOUND WD HILLSIDE SOIL DATA

PLUTONIUM DISTRIBUTION WITH PARTICLE SIZE.

(Rogers, Mound)

\begin{tabular}{|c|c|c|}
\hline Size Range, $\mu \mathrm{n}$ & \% Weight & \% Activity \\
\hline \hline$>1000$ & - & - \\
\hline 840 to 1000 & 6.9 & - \\
\hline 250 to 840 & 14.8 & 0.1 \\
\hline 125 to 250 & 11.3 & 0.5 \\
\hline 53 to 125 & 11.5 & 7.7 \\
\hline 20 to 53 & 12.5 & 15.3 \\
\hline 5 to 20 & 18.0 & 16.8 \\
\hline 2 to 5 & 6.5 & 58.3 \\
\hline$<2$ & 18.5 & \\
\hline
\end{tabular}


Table 9

MIAMI-ERIE CANAL SEDIMENT DATA

PLUTONIUM DISTRIBUTION WITH PARTICLE SIZE.

ULTRASONIC DISPERSION

(Rogers, Mound)

\begin{tabular}{|c|c|c|}
\hline Size Range, $\mu \mathrm{n}$ & \% Weight & \% Activity \\
\hline \hline$>2000$ & - & - \\
\hline 840 to 2000 & 1.9 & - \\
\hline 250 to 840 & 4.0 & - \\
\hline 125 to 250 & 2.8 & - \\
\hline 53 to 125 & 3.7 & - \\
\hline 20 to 53 & 22.2 & 6.4 \\
\hline 5 to 20 & 28.4 & 12.3 \\
\hline 2 to 5 & 7.2 & 11.8 \\
\hline$<2$ & 29.7 & 69.5 \\
\hline
\end{tabular}

Table 10

MIAMI-ERIE CANAL SEDIMENT DATA

PLUTONIUM DISTRIBUTION WITH DENSITY

(Tamura, ORNL)

\begin{tabular}{|c|c|c|}
\hline Density Range. $\mathrm{g} / \mathrm{cc}$ & \% Weight & \% Activity \\
\hline \hline$>2.9$ & 4.9 & 2 \\
\hline 2.4 to 2.9 & - & - \\
\hline 2.2 to 2.4 & 72.8 & 76 \\
\hline 2.0 to 2.2 & - & - \\
\hline 1.8 to 2.0 & 8.5 & 6 \\
\hline$<1.8$ & 5.8 & 16 \\
\hline
\end{tabular}

* The Miami-Erie Canal sediment subjected to hollow star analysis. The results of these tests indicated that the plutonium is not present as "hot particles". 
Table 11a

FIRST PASS TRUclean PERFORMANCE ON FRESH MOUND WD HILLSIDE SOIL (Sum of First Seven Runs by AWC)

\begin{tabular}{|l|c|c|c|c|c||}
\hline \multicolumn{1}{|c|}{ Stream } & $\begin{array}{c}\text { Total } \\
\text { Volume, } \\
\text { Liters }\end{array}$ & $\begin{array}{c}\% \\
\text { Volume }\end{array}$ & $\begin{array}{c}\text { Average } \\
\text { Conc., } \\
\mathrm{pCi} / \mathrm{g}\end{array}$ & $\begin{array}{c}\text { Total } \\
\text { Activity, } \\
\mu \mathrm{Ci}\end{array}$ & $\begin{array}{c}\% \\
\text { Activity, } \\
\mu \mathrm{Ci}\end{array}$ \\
\hline \hline Feed & 1782.0 & 100.0 & 106.0 & 188.9 & 100.0 \\
\hline Hutch & 45.2 & 2.5 & 69.0 & 3.1 & 1.7 \\
\hline Press & 613.0 & 34.4 & 229.6 & 140.8 & 74.5 \\
\hline Discharge & 1047.0 & 58.8 & 37.5 & 39.3 & 20.8 \\
\hline Waste & - & 10.0 & - & - & - \\
\hline
\end{tabular}

Table 11b

RECYCLE TRUclean PERFORMANCE ON DISCHARGE FROM FIRST PASS (Sum of Last Three Runs by AWC)

\begin{tabular}{||l|c|c|c|c|c||}
\hline \hline Stream & $\begin{array}{c}\text { Total } \\
\text { Volume, } \\
\text { Liters }\end{array}$ & $\begin{array}{c}\% \\
\text { Volume }\end{array}$ & $\begin{array}{c}\text { Average } \\
\text { Conc., } \\
\mathrm{pCi} / \mathrm{g}\end{array}$ & $\begin{array}{c}\text { Total } \\
\text { Activity, } \\
\mu \mathrm{Ci}\end{array}$ & $\begin{array}{c}\% \\
\text { Activity, } \\
\mu \mathrm{Ci}\end{array}$ \\
\hline \hline Feed & 919.0 & 100.0 & 32.2 & 29.6 & 100.0 \\
\hline Hutch & 15.0 & 1.6 & 55.9 & 0.8 & 2.8 \\
\hline Press & 193.0 & 21.0 & 165.2 & 31.9 & 107.6 \\
\hline Discharge & 691.0 & 75.2 & 8.9 & 6.2 & 20.8 \\
\hline Waste & - & 10.0 & - & - & - \\
\hline \hline
\end{tabular}

Table 11c

CALCULATED DUPLEX TRUclean PERFORMANCE

\begin{tabular}{||l|c|c|c||}
\hline \multicolumn{1}{|c|}{ Stream } & \% Volume & Conc.pCi/g & \% Activity \\
\hline \hline Feed & 100.0 & 106.0 & 100.0 \\
\hline Discharge & 44.2 & 8.9 & 4.3 \\
\hline Concentrate & 55.8 & - & 95.7 \\
\hline Process Waste & 15.8 & - & - \\
\hline \hline $\begin{array}{l}\text { Total LSA } \\
\begin{array}{l}\text { NET VOLUME } \\
\text { REDUCTION }\end{array}\end{array}$ & 71.6 & - & 95.7 \\
\hline
\end{tabular}


Table 12

PREDICTED TRUClean PROCESS PERFORMANCE:

WD HILLSIDE SOII CONTAMINATED WITH $1000 \mathrm{pCi} / \mathrm{g}$

SOIL CONDITIONS OF THE: WD Hillside SOII

Percent Silt-Clay in Soil Matrix

Concentration of $\mathrm{Pu}$ in Soil

$55.0 \%$
$1000 \mathrm{pCi} / \mathrm{g}$

TRUClean PROCESS

Process Waste Generation Rate ( $\%$ of Throughput)

Total Process Throughput

In-ground soil Input Rate

Soil Recycle Rate

\% Activity Removal on Each Pass

SUMMARY OF TRUCIEan RUNS

\begin{tabular}{|c|c|c|c|}
\hline & & Conc $\mathrm{Pu}$ & \% soil \\
\hline Run \# & \% Tails & $\mathrm{pCi} / \mathrm{g}$ & Concentrate \\
\hline Feed & 100.0 & 1000.0 & 0.0 \\
\hline 1 & 56.4 & 368.4 & 43.6 \\
\hline 2 & 47.4 & 91.3 & 9.1 \\
\hline 3 & 45.5 & 19.8 & 1.9 \\
\hline 4 & 45.1 & 4.2 & 0.4 \\
\hline
\end{tabular}

SUMMARY OF TRUCIEan PERFORMANCE

Total \% Activity Removed

Distribution as \% of in-ground soil Clean Discharge

Soil Concentrate (ISA)

Process Waste (ISA)

Total ISA Waste

Net Volume Reduction

$$
\begin{array}{r}
0.0 \\
10.0 \\
5.6 \\
4.7 \\
4.5
\end{array}
$$

$10 \%$

$8.0 \mathrm{cu} \mathrm{yds} / \mathrm{hr}$

$3.2 \mathrm{cu} \mathrm{Yds} / \mathrm{hr}$

$4.8 \mathrm{cu}$ yds $/ \mathrm{hr}$

$79.2 \%$

$\because$ Process

Waste

ESTIMATED COST IMPACT OF TRUClean PROCESS

(Cost of TRUClean Equipment and AWC profits not included)

Unit Process

Operations

Digging

TRUClean Process

Packaging

Disposal

Total
Unit Total cost of D\&D operation, $\$ / \mathrm{cu}$ ft

\begin{tabular}{c} 
Mound D\&D Operation \\
\hline 5.20 \\
0.00 \\
10.52 \\
$\$ \frac{72.00}{\$ 87.72}$
\end{tabular}

with TRUClean

5.20

16.65

8.40

57.65

$45.1 \%$

$54.9 \%$

$24.9 \%$

$79.8 \%$

$20.2 \%$ 
Table 13

PREDICTED TRUClean PROCESS PERFORMANCE:

MIAMI-ERIE CANAL SEDIMENT CONTAMINATED

WITH $500 \mathrm{pCi} / \mathrm{g} \mathrm{Pu}-238$.

SOIL CONDITIONS OF THE: Miami-Erie Canal Sediment Percent Silt-Clay in Soil Matrix

Concentration of $\mathrm{Pu}$ in Soil

$85.0 \%$

TRUClean PROCESS

Process Waste Generation Rate (\% of Throughput)

Total Process Throughput

In-ground soil Input Rate

Soil Recycle Rate

$\%$ Activity Removal on Each Pass

$500 \mathrm{pCi} / \mathrm{g}$

SUMMARY OF TRUClean RUNS

\begin{tabular}{l} 
Run \# \\
\hline Feed \\
1 \\
2 \\
3 \\
4
\end{tabular}

$\frac{8 \text { Tails }}{100.0}$
32.7
18.7
15.8
15.2

\begin{tabular}{r} 
Conc Pu \\
$p c i / g$ \\
\hline 500.0 \\
318.2 \\
115.8 \\
28.5 \\
6.2
\end{tabular}

\begin{tabular}{c} 
\%oil \\
Concentrate \\
\hline 0.0 \\
67.3 \\
14.0 \\
2.9 \\
0.6
\end{tabular}

\% Process

Waste

0.0

10.0

3.3

1.9

1.6

SUMMARY OF TRUClean PERFORMANCE

Total \% Activity Removed

Distribution as \% of in-ground soil

Clean Discharge

Soil concentrate (LSA)

Process Waste (ISA)

Total ISA Waste

Net Volume Reduction

$$
\begin{array}{r}
99.8 \% \\
15.2 \% \\
84.8 \% \\
16.7 \% \\
101.6 \% \\
-1.6 \%
\end{array}
$$

ESTIMATED COST IMPACT OF TRUCIEAN PROCESS

(Cost of TRUClean Equipment and AWC profits not included)

Unit Process Operations

Digging

TRUClean Process

Packaging

Disposal

Total
Unit Total cost of D\&D Operation, $\$ / C u$ ft

Mound D\&D Operation

with TRUClean

$$
5.20
$$

0.00

10.52

$\frac{72.00}{87.72}$

$\$ 87.72$

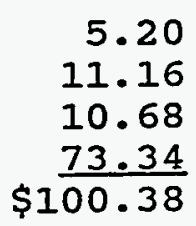


Table 14

PREDICTED TRUCIEan PROCESS DECONTAMINATION PERFORMANCE ASSUMING PROCESS IS OPTIMIZED AND WASTE GENERATION IS LOW: MIAMI ERIE CANAI SEDIMENT CONTAMINATED WITH $500 \mathrm{pCi} / \mathrm{g}$ Pu-238.

SOIL CONDITIONS OF THE: Miami-Erie Canal sediment Percent Silt-clay in Soil Matrix Concentration of $\mathrm{Pu}$ in Soil $85.0 \%$

TRUClean PROCESS

Process Waste Generation Rate (\% of Throughput) Total Process Throughput

In-ground soil Input Rate

Soil Recycle Rate

\% Activity Removal on Each Pass

$500 \mathrm{pCi} / \mathrm{g}$

SUMMARY OF TRUClean RUNS

\begin{tabular}{|c|c|c|c|}
\hline Run \# & 움as & $\begin{array}{l}\text { Conc Pu } \\
\mathrm{pCi} / \mathrm{g}\end{array}$ & $\begin{array}{l}\% \text { Soil } \\
\text { Concentrate }\end{array}$ \\
\hline $\begin{array}{l}\text { Feed } \\
1\end{array}$ & $\begin{array}{r}100.0 \\
15.0\end{array}$ & $\begin{array}{r}1000.0 \\
0.0\end{array}$ & $\begin{array}{r}0.0 \\
85.0\end{array}$ \\
\hline
\end{tabular}

\% Process

Waste

0.0

5.0

\section{SUMMARY OF TRUClean PERFORMANCE}

Total \% Activity Removed

Distribution as \% of in-ground soil

Clean Discharge

Soil Concentrate (LSA)

Process Waste (ISA)

Total ISA Waste
$5 \%$
$8.0 \mathrm{cu} \mathrm{yds} / \mathrm{hr}$
$8.0 \mathrm{cu} y d s / \mathrm{hr}$ $100.0 \%$

Net Volume Reduction

$$
\begin{array}{r}
100.0 \% \\
15.0 \% \\
85.0 \% \\
5.0 \% \\
90.0 \% \\
10.0 \%
\end{array}
$$

ESTIMATED COST IMPACT OF TRUCIEan PROCESS

(Cost of TRUClean Equipment and AWC profits not included)

Unit Process Operations

Digging

TRUclean Process

Packaging

Disposal

Total

Unit Total cost of D\&D operation, $\$ / c u$ ft

Mound D\&D Operation

5.20

0.00

10.52

$\underline{72.00}$ with TRUClean

$$
5.20
$$

6.68

9.47

$\frac{65.00}{86.35}$ 